\title{
Airborne Bacteria and Fungi Concentration in Relation with Bedding Type in Broiler Houses
}

\author{
Silvana POPESCU ${ }^{1}$, Cristin BORDA ${ }^{1 *}$, Cristina EL MAHDY ${ }^{2}$, Eva Andrea LAZAR ${ }^{1}$, Anamaria BLAGA \\ PETREAN $^{1}$, Marina SPINU ${ }^{1}$ \\ ${ }^{1}$ Faculty of Veterinary Medicine, University of Agricultural Sciences and Veterinary Medicine, Cluj-Napoca, \\ Romania \\ ${ }^{2}$ Faculty of Animal Science and Biotechnologies, University of Agricultural Sciences and Veterinary \\ Medicine, Cluj-Napoca, Romania \\ *corresponding author: cborda@usamvcluj.ro
}

Bulletin UASVM Veterinary Medicine 76(2)/2019

Print ISSN 1843-5270; Electronic ISSN 1843-5378

doi:10.15835/buasvmcn-vm:2018.0033

\begin{abstract}
:
The aim of this work was the investigation of the effect of bedding type on the airborne concentration of bacteria and fungi in broiler houses. The study was performed in two commercial farms (A and B) with different bedding (chopped straw in farm A, sunflower seed hulls in farm B). The determination of the bacteria and fungi's numbers was performed in the first and the sixth weeks of the production cycle. Both the concentration of the bacteria and fungi showed higher values in the farm A compared with the farm B, especially in the latter period of the production cycle. In both farms, significant differences $(\mathrm{P}<0.05)$ were recorded between the two periods of the determinations. The results of this study suggest that using sunflower seed hulls as bedding leads to lower levels of microbial contamination of the air in broiler houses, comparing with the use of chopped straw.
\end{abstract}

Keywords: airborne bacteria, airborne fungi, bedding materials, broiler houses

\section{Introduction}

The results of the existing studies demonstrate that the air inside the broiler houses is contaminated by high concentrations of microorganisms, especially bacteria. The health status of birds and farm workers is affected by the level of airborne microflora (Hartung, 1994; Wathes, 1998). In the same time, high levels of microbiological air pollution pose a huge threat to the natural environment surrounding poultry farms (Seedorf, 2004). Because of this, implementing management practices reducing air pollutants in animal houses represents an urgent requirement.
A few authors have assessed the content of air pollution on broiler farms with regard to the birds' age and productivity (Popescu et al., 2010; Vučemilo et al., 2007; Wójcik et al., 2010). Until, now no study investigated the concentration of airborne microorganisms in relation with the type of bedding in broiler farms. Instead, numerous studies were performed regarding the effect of bedding materials on the health and performance of the broilers (Cengiz et al. 2011; Kaukonen et al., 2016; Popescu et al., 2018).

The aim of this work was the investigation of the effect of bedding type (chopped straw vs. sunflower seed hulls) on the airborne 
Table 1. Descriptive statistical indicators for mesophilic bacteria and fungi in farms A and B and the significance of the difference in relation with the age of the birds and type of bedding

\begin{tabular}{|c|c|c|c|c|c|c|c|}
\hline & Parameter & $\begin{array}{c}\text { Age of } \\
\text { birds } \\
\text { (weeks) }\end{array}$ & Mean & $\begin{array}{l}\text { Standard } \\
\text { deviation }\end{array}$ & Median & Minimum & Maximum \\
\hline \multirow{4}{*}{ Farm A } & \multirow{2}{*}{$\begin{array}{c}\text { Mesophilic } \\
\text { bacteria } \\
\left(\mathrm{cfu} / \mathrm{m}^{3}\right)\end{array}$} & 1 & $8.84 \times 10^{5}$ & $0.77 \times 10^{4}$ & $8.85 \times 10^{5}$ & $6.75 \times 10^{5}$ & $1.09 \times 10^{6}$ \\
\hline & & 6 & $4.46 \times 10^{6}$ & $5.14 \times 10^{5}$ & $4.98 \times 10^{6^{*}}$ & $3.36 \times 10^{6}$ & $8.99 \times 10^{6}$ \\
\hline & \multirow{2}{*}{$\begin{array}{c}\text { Fungi } \\
\left(\mathrm{cfu} / \mathrm{m}^{3}\right)\end{array}$} & 1 & $1.49 \times 10^{3}$ & $3.84 \times 10^{2}$ & $1.52 \times 10^{3}$ & $7.34 \times 10^{2}$ & $1.72 \times 10^{3}$ \\
\hline & & 6 & $2.64 \times 10^{4}$ & $4.41 \times 10^{3}$ & $2.65 \times 10^{4^{*}}$ & $2.05 \times 10^{4}$ & $3.25 \times 10^{4}$ \\
\hline \multirow{4}{*}{ Farm B } & \multirow{2}{*}{$\begin{array}{c}\text { Mesophilic } \\
\text { bacteria } \\
\left(\mathrm{cfu} / \mathrm{m}^{3}\right)\end{array}$} & 1 & $8.76 \times 10^{5}$ & $1.25 \times 10^{5}$ & $8.67 \times 10^{5}$ & $7.07 \times 10^{5}$ & $1.03 \times 10^{6}$ \\
\hline & & 6 & $2.07 \times 10^{6}$ & $2.19 \times 10^{5}$ & $2.09 \times 10^{6^{*}}$ & $1.70 \times 10^{6}$ & $2.13 \times 10^{6}$ \\
\hline & \multirow{2}{*}{$\begin{array}{c}\text { Fungi } \\
\left(\mathrm{cfu} / \mathrm{m}^{3}\right)\end{array}$} & 1 & $1.27 \times 10^{3}$ & $2.74 \times 10^{2}$ & $1.22 \times 10^{3}$ & $1.03 \times 10^{3}$ & $1.62 \times 10^{3}$ \\
\hline & & 6 & $2.37 \times 10^{4}$ & $3.34 \times 10^{3}$ & $2.34 \times 10^{4^{*}}$ & $1.97 \times 10^{4}$ & $2.81 \times 10^{4}$ \\
\hline
\end{tabular}

${ }^{*} \mathrm{P}<0.05$ the difference is significant

concentration of bacteria and fungi in broiler houses.

\section{Materials and methods}

The research was performed in two commercial broiler farms (farm A and B) in Romania. In both farms, the chickens were raised in similar conditions (ventilation, lighting, heating, feeding and watering) on permanent bedding, chopped straw in farm A, sunflower seed hulls in farm B. In farm A, 64000 chickens were reared in two houses $\left(1680 \mathrm{~m}^{2} /\right.$ house), with a density of $39 \mathrm{~kg} / \mathrm{m}^{2}$ and farm B had 140000 chickens in five houses $\left(1560 \mathrm{~m}^{2} /\right.$ house), with $42 \mathrm{~kg} / \mathrm{m}^{2}$ density. In both farms, the birds were ROSS 308, and they were slaughtered at 40-44 days of age.

The collection of air samples for the determination of the bacteria and fungi's numbers was done with a Merck MAS-100 device in the first and the sixth weeks of the production cycle. The samples were collected in the centre and at both ends of two houses (6 determinations / house) with similar numbers of birds (32000 chickens/house) in each of the farms. Bacteria and fungi were collected in Petri dishes on different standard culture mediums: Columbia agar for mesophilic bacteria and Sabouraud agar for fungi. The air was sampled in a volume of $1 \mathrm{~L}$ because preliminary studies show that bacteria and fungi are in great numbers in poultry barns. Plates with the usual bacterial nutrient Columbia agar were then incubated for $24 \mathrm{~h}$ at $37^{\circ} \mathrm{C}$ and those on Sabouraud agar were incubated for 5 days at $22^{\circ} \mathrm{C}$. The grown colonies were calculated by a mechanical optic colony counter, and the results were corrected using the conversion formula devised by Feller (1950). The average number of bacteria and fungi was calculated as colonyforming units in one cubic metre $\left(\mathrm{cfu} / \mathrm{m}^{3}\right)$. All data were analysed with SPSS version 17 software. Descriptive statistical indicators (mean, standard deviation, median, minimum and maximum) of the number of mesophilic bacteria and fungi were calculated. These results were compared between the farms using the Mann-Whitney test. The differences were considered significant if $\mathrm{P}<0.05$.

\section{Results and discussion}

The number of mesophilic bacteria and fungi varied in the investigated farms (Table 1). The determined values are in line with those obtained in other studies that show that in broiler houses, the cultivable concentrations of bioaerosols range from $10^{4}$ to $10^{7} \mathrm{cfu} / \mathrm{m}^{3}$ for mesophilic bacteria and from $10^{2}$ to $10^{5} \mathrm{cfu} / \mathrm{m}^{3}$ for fungi (Bakutis etal., 2004; Popescu et al., 2010; Radon et al., 2002; Seedorf et al., 1998; Vučemilo et al., 2007). The concentration of airborne microorganisms in poultry housing reported in literature varies greatly, which could, in part, be explained by different sampling methods used in several studies (Lonc and Plewa, 2010; Vucemilo et al., 2007). The microbial load of the air, in terms of mesophilic bacteria, is influenced by several factors, such as the numbers of sheltered 
birds, the breeding technology, the floor type, the bedding materials, the microclimatic conditions, the dust concentration, and the ventilation level (Radon et al., 2002; Wathes, 1998).

In both farms, the total number of mesophilic bacteria exceeded the recommended value $(2.50$ x $10^{5} \mathrm{cfu} / \mathrm{m}^{3}$, Decun, 1997), 3.5 times in the first week, and in the last period of the production cycle 17.8 times in farm A and 8.3 times in farm B.

Even if the differences between the farms were not statistically significant $(P>0.05)$, yet the numbers of mesophilic bacteria and fungi was higher in farm A than in farm B, especially at the end of the production cycle (Table 1). A higher difference was recorded for mesophilic bacteria in the sixth week, the numbers being double in the farm A compared with the farm B. As regards the fungi, the difference between the farms was lower than for the bacteria (Table 1). Because in both farms the numbers of chicken and the rearing and housing conditions were similar, except for the type of bedding, this difference may be due to the bedding material used. Although both materials are considered adequate in the broiler industry, it is possible that the chopped straw produced more dust than the sunflower seed hulls and it resulted in a higher microbial load of the air. Otherwise, it is recognized that husks make excellent litter because of their large particle size and lack of dust (Miller, 2004). A recent study of Popescu et al. (2018) shows that the welfare of the broiler chicken (assessed based on health and environment related indicators) is more appropriate when sunflower seed hulls are used as bedding compared with chopped straw. Probably this result is due also to the lower airborne microbial pollution in those poultry houses using sunflower seed hulls as bedding.

In both farms, the age of the birds influenced significantly the airborne bacteria and fungi concentrations, the microbial air contamination increased simultaneously with the fattening period. This aspect was also shown in other studies (Popescu et al., 2010; Vučemilo et al., 2007).

\section{Conclusion}

The results of this study suggest that using sunflower seed hulls as bedding leads to lower levers of microbial contamination of the air in broiler houses, comparing with the use of chopped straw. Further investigation is needed to establish the extent to which our findings can be generalized.

Acknowledgments. This research did not receive any specific grant from funding agencies in the public, commercial, or not-for-profit sectors.

\section{References}

1. Bakutis B, Monstviliene E, Januskeviciene G (2004). Analyses of airborne contamination with bacteria, endotoxins and dust in livestock barns and poultry houses. Acta Vet Brno, 73, 283-289.

2. Cengiz O, Hess JB, Bilgili SF (2011). Effect of bedding type and transient wetness on footpad dermatitis in broiler chickens. J Appl Poult Res, 20, 554-560.

3. Decun M (1997). Airborne microflora. In: Veterinary Hygiene and the protection of the environment (in Romanian, pp. 82-85). Helicon, Timisoara.Feller, W. (1950). An introduction to the probability theory and its application. John Wiley \& Sons Inc., New York (vol.1).

4. Hartung J (1994). The effect of airborne particulates on livestock health and production. In: I. A P Dewi, R F E Axeford, I Fayez, M Marai, H Omed (Eds.), Pollution in Livestock Production Systems (pp. 55-69). CAB International, Wallingford.

5. Kaukonen E, Norring M, Valros A (2016). Effect of litter quality on foot pad dermatitis, hock burns and breast blisters in broiler breeders during the production period. Avian Pathol , 45(6), 667-673.

6. Lonc E, Plewa K(2010). Microbiological Air Contamination in Poultry Houses. Polish J of Environ Stud, 19 (1 ), 15-19.

7. Miller J (2004). Alternative litter materials for poultry. In: Agfact A5.1.9 (pp. 1-5). Division of Agricultural Services, New South Wales.

8. Popescu S, Borda C, Hegedus CI, Stefan R, Lazar EA (2010). The Microbiologic Quality of the Air in Broiler Houses. Scientific Papers: Animal Science and Biotechnologies, 43(2), 119-123.

9. Popescu S, El Mahdy C, Diugan EA, Blaga Petrean A, Borda C (2018). The Effect of Bedding Type on the Welfare Quality of Broiler Chickens. Scientific Papers: Animal Science and Biotechnologies, 51 (1), 86-91.

10. Radon K, Danuser B, Iversen M, Monso E, Weber C, Hartung J, Donham K, Palmgren U, Nowak D (2002). Air Contaminants in Different European Farming Environments. Ann Agric Environ Med, 9(1), 41-48.

11. Seedorf J (2004). An emission inventory of livestockrelated bioaerosols for Lower Saxony, Germany. Atmos Environ, 38(38), 6565-6581.

12. Seedorf J, Hartung J, Schröder M, Linkert KH, Phillips VR, Holden MR, Sneath RW, Short JL, White RP, Pedersen S, Takai T, Johnsen JO, Metz JHM, Groot Koerkamp PWG, Uenk GH, Wathes CM (1998). Concentrations and emissions of airborne endotoxins and microorganisms in livestock buildings in Northern Europe. J Agr Eng Res, 70(1), 97109. 
13. Vučemilo M, Matković K, Vinković B, Jakšić S, Granić K, Mas N (2007). The effect of animal age on air pollutant concentration in a broiler house. Czech J Anim Sci, 52 (6), 170-174.

14. Wathes CM (1998). Aerial emissions from poultry production.World's Poultry Sci J, 54, 241.
15. Wójcik A, Chorąży L, Mituniewicz T, Witkowska D, Iwańczuk-Czernik K, Sowińska J (2010). Microbial air contamination in poultry houses in the summer and winter. Polish J Environ Stud, 19, 1045-1050. 